\title{
INTERFERENCE OF MALAY MANADO LANGUAGE TOWARD INDONESIAN LANGUAGE BY STUDENTS' SPEECH IN GORONTALO STATE UNIVERSITY
}

\author{
Abdul Kadir Ismail, Hamzah A. Machmoed and Moses Usman \\ Email: abdulkadir89@ymail.com \\ Linguistic Studies Program, Cultural Sciences Faculty, Hasanuddin University
}

\begin{abstract}
Interference of Malay Manado Language in Formal Spoken Indonesian Language: "A Case Study at Indonesian Language Studies, Gorontalo State University" .This research aims to elaborate the kinds of interference in Malay Manado Language toward Indonesian Language on students' speech in class discussion performance and to describe the most frequent of interference that students produced in class discussion performance by students in Indonesian Language Studies. Besides, the purpose of this research is to disclose the students deal with the interference on their speech in class discussion performance.The research was conducted in Indonesian Language Studies, Gorontalo State University. The data were collected from students' speech in class discussion performance by using recording technique. The samples were 30 respondents. Two methods in analyzing data, namely descriptive quantitative and qualitative methods. There are three kinds of interference that students produced on students' speech in class discussion performance namely phonological interference, morphological interference, and lexical interference. Firstly, in phonological interference can be categorized into assimilation, merger colescence or diftong, syncope, apocope, compression, and vowel modification. In morphological interference, they produced prefix addition, imperative form, reduplication, compounding form, and negation form. In Lexical interference, they created nine types of interference namely verb, noun, adjective, pronoun, adverb, question form, language particle, possesive, and preposition. Secondly, the most frequent type of interference on students' speech in class discussion performance is lexical interference. It is about 193 in the percentage $59.38 \%$. Lastly, there are some factors that causing interference on students' speech. They are, bilingualism, the lack of using Indonesian Language, needs for synonyms and the last is students' high prestige.
\end{abstract}

Interferensi bahasa Melayu Manado terhadap bahasa Indonesia pada tuturan mahasiswa di Universitas Negeri Gorontalo. Tujuan dari penelitian ini adalah untuk menguraikan jenis-jenis interferensi yang terjadi pada tuturan mahasiswa dalam kelas diskusi oleh mahasiswa jurusan bahasa Indonesia dan mendeskripsikan frequensi interferensi yang paling banyak diproduksi oleh mahasiswa dalam proses diskusi di dalam kelas. Data dikumpulkan dari tuturan mahasiswa di dalam kelas diskusi dengan menggunakan dua tehnik yaitu tehnik rekaman dan metode simak. Sampel dari penelitian ini adalah 30 responden. Peneliti menggunakan metode deskriptif kuantitatif dan kualitatif dalam menganalisis data. Terdapat tiga jenis interferensi yang diproduksi oleh mahasiswa pada tuturannya di dalam kelas diskusi yaitu interferensi fonologi, interferensi morfologi, dan interferensi leksikal. Pertama, interferensi fonologi dapat dikelompokkan menjadi asimilasi, penggabungan koalisi atau diftong, syncope, apocope, compression, dan modifikasi vokal. Dalam interferensi morfologi mereka memproduksi penambahan prefix, betuk perintah biasa, reduplikasi, pemajemukan, dan bentuk negasi. Terdapat sembilan jenis interferensi yaitu interferensi pada kata kerja, benda, kata sifat, kata ganti orang atau benda, kata keterangan, bentuk pertanyaan, partikel bahasa, bentuk kepunyaan, dan kata depan. Kedua, frekuensi interferensi yang tertinggi pada tuturan mahasiswa di kelas diskusi adalah interferensi leksikal. Interferensi tersebut sekitar 193 dengan persentase $59.38 \%$. Ada beberapa faktor yang menyebabkan terjadinya interferensi pada tuturan mahasiswa yaitu adanya kedwibahasaan, kurangnya pemakaian bahasa Indonesia, kebutuhan akan sinonim dan prestise yang menyebabkan tingginya tingkat interferensi.

Keywords: Malay Manado Language, Indonesian Language, Phonological, Morphological, Lexical Interference 
Journal al-Lisan

ISSN 2442-8965 \& E ISSN 2442-8973

Volume 4 Nomor 1 -Februari 2018

http://journal.iaingorontalo.ac.id/index.php/al

\section{A. Introduction}

Indonesian society is bilingual in spoken, meaning many people used two languages. In the communication process, Indonesian is used as a national language than local language in each area. Both languages are sometimes used in their daily life in the same time, both orally and in written. This situation enables the influence of language contact. Mutual influence can be seen in the use of the Indonesian language inserted into the local language vocabulary or in reverse that includes all levels. The researcher found out the same statement or problem above, also occurs in the communication activities in daily life in Gorontalo city, especially on students' in Gorontalo State University. They used Indonesian language where get interference of Malay Manado language in their interaction even in formal and non formal situation. The phenomena of interference came from language contact. Suwito (1983), states that the existence of irregularities does not mean the destruction of language. Interference is a phenomenon of linguistic rules deviation caused by one person mastering two languages or more. Besides, interferences are deviation because the element is absorbed by an already existing language in the language equivalent absorbent. Thus, the manifestation caused of the interference is the ability to use language by the speakers in particular. In terms of language, interference can be divided in two categories, namely interference in form and interference in meaning. According to Poedjisoudarmo (1982), interference form includes elements of language and language variations, while the interference meaning includes lexical, morphological, and syntactical interference. Interference according to Nababan (1991), is an error that occurs because of the speech habits of the local language or dialect entering a language or the second dialect.

Similarly, Chaer et al (1995), argue that interference is the norm of deviation events from one language to another. The existence of bilingualism will also cause interference and language integration. Language interference is linguistic norm deviations that occur in bilingual speech because of its familiarity to more than one language often due to language contact. Furthermore language contact factor is causing interference according to Weinreich in Weda (1998), states that in sufficient vocabulary of a language in the face of progress and reform. Additionally, the disappearance of words that are rarely used depends on them being synonymous and on the prestige of the source language. Bilingual speaker and lack of loyalty to the recipient language are also as the factor contributing to the interference. 
Journal al-Lisan

ISSN 2442-8965 \& E ISSN 2442-8973

Volume 4 Nomor 1 -Februari 2018

http://journal.iaingorontalo.ac.id/index.php/al

The research about interference has been done by many researchers in this world such as Suindartini (2013), investigated the interference in Balinese and foreign languages in oral stories in Indonesian language in junior high school students, grade VII SMP 10 Denpasar. The results showed that in Balinese language interference, there are four types of interference namely phonological interference, morphological, syntactic, and semantic interference. While the interference of foreign language she got interference of syntax and semantic. Besides, Weda (1998), focused his research on Inter-language Phonology: stress shifts of English utterances made by Indonesian speakers of English. He tried to describe English stress shifts which occur in English utterances made by Indonesian speakers of English. While in Gorontalo, a study on interference was carried out by some researchers, one of them is Pidu (2011), examineds the Language Interference of Malay Manado Dialect in Gorontalo Language in the South Dulomo, in Family domain. Findings show that the use of other dialect, namely Malay Manado dialect in the family domain are intensifying pressure on Gorontalo language, and the mixing of ethnic groups in the village becomes a major factor affecting the reduction in the use of Gorontalo language.

Different from several previous studies above, this study described and elaborated on the kinds of the interference form Malay Manado Language toward Indonesian language that focuses on phonological, morphological and lexical interferences by students' speech in Gorontalo State University. Generally, Gorontalo people only use Malay Manado language to communicate each other in their daily life, and usually occur among children, teenagers, adults, and even in the family domain, education domain, and in the Gorontalo society domain. It always happens because of the Indonesian speech community and Malay Manado people stay coexists in Gorontalo province. Therefore the interference occurs both of these languages. Hence, the focus of this study is the interference of Malay Manado Language toward Indonesian language in Indonesian Language Studies. It is because of the best of researcher's knowledge so far, students in Indonesian Language Studies get interference when had class discussion performance. Therefore, one of the aims of this study was to elaborate the kinds of interference that influence Indonesian Language on students' speech in Indonesian Language Studies. 
Journal al-Lisan

ISSN 2442-8965 \& E ISSN 2442-8973

Volume 4 Nomor 1 -Februari 2018

http://journal.iaingorontalo.ac.id/index.php/al

\section{B. Method}

This research used descriptive qualitative method. The descriptive qualitative method is to obtain information about phenomenon when research is conducted (Furchan, 2004). The population was students in Gorontalo State University, Indonesian Language Studies. The sample was 30 respondents in Indonesian Language Studies. In collecting data, the researcher used three steps of collecting data. The first step is Simak method. Simak method is a method which is performed when the researcher is "hearing" students' discussion. The second step is technique of recording data which means a technique that use tape-recorder in order to get the data. According to Mahsun (2012), when the first and the second technique used, recording data can be done as well with tape-recorder as a tool. The last step is technique of note taking. Technique of note taking can be defined as an activity to write the data that recorded.

Firstly, the researcher started made a transcription of all data (such as class discussion performance "speech"). Then, the researcher identified the interference occurred. Secondly, the kinds of interference in the data were recorded. The researcher classified the collect data by tabulating them into table and describes them. Third, the researcher used descriptive qualitative terms in analyzing the data. The researcher explained the various kinds of interference Malay Manado language toward Indonesian language. Fourth, the types of interference made by respondents would be classified. Lastly, the researcher draw conclusions about the kinds of interference of Malay Manado language toward Indonesian Language that occurred by students' speech in class discussion performance, and the most frequent interference produced by the students.

\section{Findings and Discussion}

Based on the data collected, the researcher found 325 kinds of interference. They are found 60 sounds having phonological interference, there are found 72 morphology interference and lasty there are found 193 having lexical interference from students class discussion performance.

\section{Phonological Processes and Types of sound change}

The types of processes in phonological interference in this changing were namely assimilation, merger coalescence or diftong, syncope, apocope, compression and vowel modification. The following is the explanation concerning the findings data of students' interference of Malay Manado Language toward Indonesian Language in phonological aspect. 


\section{Assimilation}

Assimilation is when one sound makes another sound change. Based on data findings there are some words occurred in assimilation process. In this study, the assimilation process happened in the sounds vowel /3/ become vowel /a/ and sometimes become vowel $/ \mathrm{u} /$ between consonant, because in phonetic rules, the position both of them are middle-low. So, the vowel $/ 3 /$ changed become vowel /a/. The sounds change can be seen on some data below:

$\begin{array}{ll}\text { Phonological data } \\ \text { /kesana/ } & \rightarrow \text { [kasana] } \\ \text { /berapa/ } & \rightarrow \text { [barapa] } \\ \text { /belum/ } & \rightarrow \text { [bulum] } \\ \text { /semua/ } & \rightarrow \text { [samua] } \\ \text { /sebentar/ } & \rightarrow \text { [sabantar] }\end{array}$

\section{Merger Coalescence or Diphthong}

Merger Coalescence or diphthong is two vowel sounds pronounced as one syllable. It usually happened in the last phoneme of the words. This process also occured on students' speech in class discussion performance. It can be seen on data below:

$$
\begin{aligned}
& \text { 1) } / \mathbf{a u} / \rightarrow[0] / \\
& / \text { kalau/ } \rightarrow \text { [kalo] } \\
& / \mathrm{mau} / \rightarrow[\mathrm{mo}] \\
& / \mathrm{kau} / \rightarrow[\mathrm{ko}] \\
& \text { 2) } / \mathbf{a i} / \rightarrow[\mathrm{e}] / \\
& \text { /sampai/ } \rightarrow \text { [sampe] } \\
& \text { /dipakai/ } \rightarrow \text { [dipake] } \\
& \text { /ramai/ } \rightarrow \text { [rame] } \\
& \text { 3) } / \mathbf{i a} / \rightarrow[\mathbf{a}] / \mathbf{C} \longrightarrow \mathbf{C} \\
& \text { /siapa/ } \rightarrow \text { [sapa] } \\
& \text { 4) } / \mathbf{a i} / \rightarrow[\mathbf{i}] / \mathrm{C} \_ \text {C } \\
& \text { /bagaimana/ } \rightarrow \text { [bagimana] }
\end{aligned}
$$

\section{Syncope}

Syncope refers to the loss of unstressed vowels in the middle of words. It is syncope which often produces consonant clusters in languages that did not formerly have them. Syncope had been done by samples. Data instance can be seen below:

$/$ terima/ $\rightarrow$ [trima]

$/$ karena/ $\rightarrow$ [karna] 
/sekali/ $\rightarrow$ [skali]

/sedikit/ $\rightarrow$ [sadiki]

/sekalian/ $\rightarrow$ [skalian]

/sekarang/ $\rightarrow$ [ skarang]

Apocope

Apocope is loss of the final segment of the word and final vowels. This is a very common change in languages. Missing the final segment of the word was occurred in Malay Manado language toward Indonesian language. Look at the following changes that occurred in samples:

$$
\begin{aligned}
& \text { /tempat/ } \rightarrow \text { [tampa] } \\
& \text { /ikut/ } \rightarrow \text { [iko] } \\
& \text { /ikut-ikut/ } \rightarrow \text { [iko-iko] } \\
& \text { /pendek/ } \rightarrow \text { [pende] } \\
& \text { /lidah/ } \rightarrow \text { [lida] } \\
& / \text { tambah } / \rightarrow \text { [tamba] }
\end{aligned}
$$

\section{Compression}

Compression is the process of dropping off one or more syllables from the end or middle of a word. Look at the following changes that occurred in data:

$$
\begin{aligned}
& \text { /jangan/ } \rightarrow[\text { jang }] \\
& \text { /coba/ } \rightarrow[\mathrm{co}] \\
& \text { /sudah/ } \rightarrow[\text { so }] \\
& \text { /terima kasih/ } \rightarrow \text { [makasih] }
\end{aligned}
$$

\section{Vowel Modification}

Vowel modification is a change in vowel as a result of the influence other sounds that follow. In data findings, some of students produced vowel modification. In this vowel modification process, there are some variations changed process happened. There are middle -low vowel /e/ become high front vowel /i/, middle -low vowel /e/ become high back vowel /u/, sometimes phoneme addition in last words, and high back vowel /u/, become high back vowel /o/. The complete data changed can be seen bellow:

$$
\begin{aligned}
& \text { */e/ } \rightarrow[\text { i/ }] \text { / C_C } \\
& \text { /kenapa/ } \rightarrow \text { [kinapa] } \\
& * / \mathbf{e} / \rightarrow \text { [u] / C_C } \\
& \text { /terus/ } \rightarrow \text {.[turus] } \\
& * \boldsymbol{\emptyset} \rightarrow[\mathbf{n}] / \text { _ \# } \\
& \text { /Cuma/ } \rightarrow \text { [cuman] }
\end{aligned}
$$


Journal al-Lisan

ISSN 2442-8965 \& E ISSN 2442-8973

Volume 4 Nomor 1 -Februari 2018

http://journal.iaingorontalo.ac.id/index.php/al

$* / \mathbf{u} / \rightarrow[\mathbf{0}] /$ C_C

/hidup/ $\rightarrow$ [hidop]

$* / \mathbf{a} / \rightarrow[\mathbf{0}] /$ _

\section{Morphological Processes}

In this study, one of morphological processes was prefix. Prefix in Malay Manado language are, $\boldsymbol{b a}$-, $\boldsymbol{t a} \boldsymbol{a}-\boldsymbol{m a} \boldsymbol{a}$, or $\mathbf{m o}$. Look at the following changes of the prefix from students' speech in Indonesian language toward Malay Manado language that occurred:

\section{Data 1}

$$
\begin{aligned}
& \underline{\text { Tadi }} \underline{\text { kita }} \underline{\text { ba }} \underline{\text { dengar..... }} \\
& \text { Adv } 1^{\text {st }} \text { PS Pref dengar.... } \\
& \text { 'tadi saya mendegarkan...' } \\
& \text { 'I was listening' }
\end{aligned}
$$

Imperative Form

Imperative form is the form of a verb that is usually used for giving orders. On students' speech in class discussion performance, the researcher found this fenomena. The data can be seen below:

\section{Data 2}

Pertanyaan selanjutnya, wey, capat jo!

Pertanyaan selanjutnya, Part, cepat Part

'Pertanyaan selanjutnya, hei cepat saja!'

\section{Reduplication}

'The next question, Hei be quickly please!

Reduplication is when a word an element of a word, or phrase is repeated. It can often result in change of meaning or tune. The researcher found some reduplication form in students' speech. For instance:

\section{Data 3}

Dia suka ba baca puisi di tampa-tampa yang rame

$3^{\text {rd }}$ PS suka Pref baca puisi di Red yang ramai

'Dia suka membaca puisi di tempat-tempat yang ramai'

\section{'He/She like to read a poem in a crowded places'}


Journal al-Lisan

ISSN 2442-8965 \& E ISSN 2442-8973

Volume 4 Nomor 1 -Februari 2018

http://journal.iaingorontalo.ac.id/index.php/al

\section{Compounding Form}

Compounding is the process of word formation that creates compound lexems. It occurs when two or more words are joined to make one longer word. It can be seen bellow:

\section{Data 4}

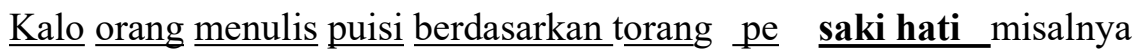
Kalo orang menulis puisi berdasarkan $1^{\text {st }}$ PPl Poss Comp misalnya

'Kalau orang menulis puisi berdasarkan sakit hatinya kita misalnya'

' For example, If people write a poem base on our broken heart'

\section{Negation Form}

Negative form interference also occurred in students' speech class discussion performance. The data cen be seen below:

\section{Data 5}

$\underline{\text { Saya }} \underline{\text { bulum mangarti dengan }} \underline{\text { isi }} \underline{\text { dari karya }} \underline{\text { ilmiah itu }}$

Saya Neg mengerti dengan isi dari karya ilmiah itu

'Saya belum mengerti isi karya ilmiah itu'

\section{'I do not understand yet the content of that scientific writing'}

\section{Lexical Process}

Based on data analysis, the researcher found some kinds of lexical interference of Malay Manado language toward Indonesian language that occurred. They are in verb, noun, adjective, personal pronoun, adverb, question form, language particle, possessive and preposition.

\section{a) Verb}

\section{Data 6}

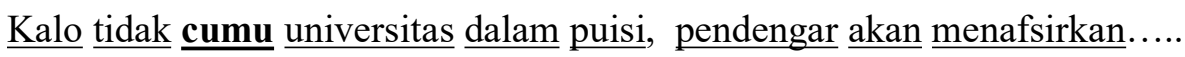

Kalau tidak Verb universitas dalam puisi,pendengar akan menafsirkan

'Kalau tidak menyebut universitas dalam puisi pendengar akan menafsirkan...'

'if you/we do not mention University in a poem,the listener will give definition....'

\section{b) Noun}

\section{Data 7}

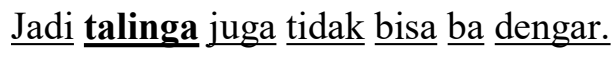

Jadi Noun juga tidak bisa Pref dengar 
'Jadi telinga juga tidak bisa mendengar'

\section{So, I can not listen well"}

\section{c) Adjective}

\section{Data 8}

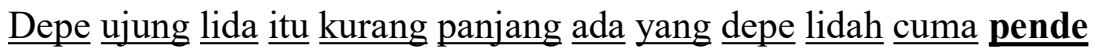

Poss ujung lidah itu kurang panjang ada yang Poss lidah hanya Adj

'Ujung lidahnya itu kurang panjang ada yang lidahnya hanya pendek'

'The top tongue is not long, there is human has a short tongue'

\section{d) Personal Pronouns}

\section{Data 9}

\section{e) Adverb}

Ngana jawab kasana saja supaya tida ba tunggu bagini

$2^{\text {nd }} \mathrm{PS}$ jawab kasana saja supaya tidak Pref tunggu Part

'Kamu jawab saja, agar tidak menunggu seperti ini'

'Just please you answer it, so we do not keep wating like this'

\section{Data 10}

Tidak sampe dipenyimpangan puisi

Tidak Adv dipenyimpangan puisi

'Tidak sampai pada penyimpangan puisi'

\section{f) Question Form}

'It is not until on the deviation of poem'

\section{Data 11}

$\underline{\text { Sapa }} \underline{\text { so moderator? }}$

Ques Part moderator?

'Siapa ya moderator?'

'Who is actually moderator?'

\section{g) Possesive}

\section{Data 12}

Begitu saya pe maksud!

Begitu saya Poss maksud!

'Begitu maksud saya'

'That is, I mean'

\section{Data 13}

Penjelasannya tidak tepat! depe jawaban agak rancu

Penjelasannya tidak tepat! Poss jawaban agak rancu

'Penjelasannya tidak tepat! jawabannya agak rancu'

'The explanation is not clear, the answer are wrong'

h) Language Particle 'Pa'

\section{Data 14}

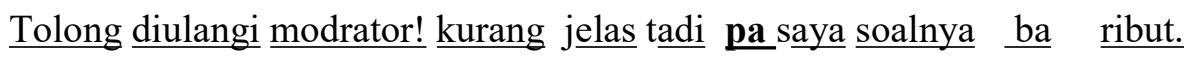


Journal al-Lisan

ISSN 2442-8965 \& E ISSN 2442-8973

Volume 4 Nomor 1 -Februari 2018

http://journal.iaingorontalo.ac.id/index.php/al

Tolong diulangi moderator! Kurang jelas tadi Part saya soalnya Pref ribut

'Tolong diulangi moderator! Kurang jelas pada saya karena ribut'

'Moderator, Repeat please! It is unclear on me because its very crowded'

'Mo'

Data 15

$\underline{\text { Kalo bukunya masih mo dipesan }}$

Kalau bukunya masih Part dipesan

'Kalau untuk bukunya masih mau dipesan'

'The books still on the ordering'

'Vor' or 'for'

Data 16

Dia suka sesuatu itu, ada untung ndak vor dia.

$3^{\text {rd }}$ PS suka sesuatu itu, ada untung Part $\overline{\text { Part }} 3^{\text {rd }}$ PS

'Dia suka sesuatu itu, ada untung tidak buat dia'

'Nyanda'

'He/She likes something, is there adventages or not for her/him'

Data 17

'Lebe'

Nyanda ada pengertian-pengertian

Neg ada pengertian-pengertian

'Tidak ada bicara definisinya'

'No talking definition here!'

Kalo Romeo dan Juliet dengan Uda dan dara lebe dulu yang mana?

Kalau Romeo dan Juliet dengan Uda dan Dara Part Part yang mana?

'Kalau Romeo dan Juliet dengan Uda dan Dara lebih dahulu yang mana?

'Which one the first published between Romeo and Juliet or Uda dan Dara'

'Dapa'

Data 19

Jangan yang hanya dapa nilai 100 yang di apresiasi.

Jangan yang hanya Part nilai 100 yang di apresiasi

'Jangan yang hanya dapat nilai 100 yang di apresiasi'

'So'

'You can not give appreciation just for the student got a best score(100)'

Data 20

'Baku'

$\underline{\text { Ok. Trima kasih so bagitu }}$

Ok. Terima kasih Part Part

Ok. Terima Kasih sudah seperi itu

'Ok, Thank you. Like that'

Data 21

Tidak apa-apa baku maso juga... 
Tidak apa-apa Part masuk juga

'Tidak masalah, saling berhubungan juga...'

'It is OK. It is releated to...'

'Cuma' or 'Cuman'

\section{Data 22}

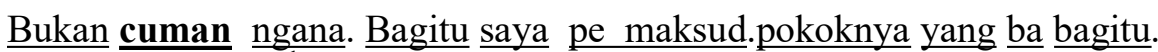
Bukan Part $2^{\text {nd }}$ PS. Part saya Poss maksud pokonya yang Pref Part 'Bukan hanya kamu. Begitu maksud saya. Pokoknya yang seperti itu'

'Not only you. It is I mean. Just like that'

'Stou'

\section{Data 23}

'Bagitu'

Tentang teorinya....apa stou...slide yang ka dua (2) Tentang teorinya.....apa Part...slide yang Prep dua(2)

'Tentang teorinya.....apa ya... slide yang ke dua(2)'

'About the theory...what is..Second slide please'

Data 24

'Bagini'

$$
\begin{aligned}
& \text { Bagitu saya pe maksud } \\
& \text { Part saya Poss maksud } \\
& \text { 'Begitu maksud saya' } \\
& \text { 'That is I mean!' }
\end{aligned}
$$

\section{Data 25}

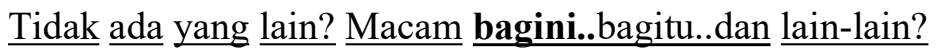

Tidak ada yang lain? Macam Part ...Part...dan lain- lain?

'Tidak ada yang lainnya? Seperti begini...begitu...dan lain-lain?'

'What about the others? Like this..like that..and so on?'

'Jo'

Data 26

Biar jo! Supaya dia bertanya

Biar Part! Supaya $3^{\text {rd }}$ PS bertanya

'Biarkan saja agar dia bertanya'

'Kase'

'Let him in order he give question'

Data 27

Tiga-tiga ini kase satu atau?

Tiga- tiga ini Part satu atau?

'Tiga-tiganya dsatukan atau?

'These three will be one or?'

'Napa'

$\underline{\text { Napa dang! Mana itu? }}$ 
Part Part! Mana itu?

'Ini dia, mana itu?

'Here it is.where is it?'

'Sampe'

Data 29

Ini kelompok dua, jangan sampe macam kelompok ini ya! Ini kelompok dua, jangan Part macam kelompok ini ya! Ini kelompok dua, jangan sampai macam kelompok ini ya!

'Toh'

'For group two, I do not like you seems like this group'

Data 30

'Dulu'

Sastra itu puisi toh?

Sastra itu puisi Part?

'Satra itu puisi kan?

'Art is a poem right?

Data 31

Apa dulu?...e...

Apa Part? ...e..

'Apa ya?...e...'

'What is?..emm...'

'Dang'

\section{Data 32}

Maksudnya dapat dipertanggung jawabkan dasar-dasar depe fakta dang

Maksudnya dapat dipertanggung jawabkan dasar-dasar Poss fakta Part

'Maksudnya dapat dipertanggung jawabkan dasar-dasar faktanya ya'

'It is mean that we can responsible with the main fact. Isn't it?

'Co'

Data 33

Co anda jelaskan kembali tentang remedial?

Part anda jelaskan kembali tentang remedial?

Coba anda jelaskan kembali tentang remedial?

'Trus'

'Please you just explain again about remedial?'

Data 34

Trus hasil pengetahuan itu apa?

Part hasil pengetahuan itu apa?

'Terus hasil pengetahuan itu apa?'

'And than, what is the result of the knowledge?' 
Journal al-Lisan

ISSN 2442-8965 \& E ISSN 2442-8973

Volume 4 Nomor 1 -Februari 2018

http://journal.iaingorontalo.ac.id/index.php/al

\section{Preposition}

\section{Data 35}

$\underline{\text { Yang ka dua apa? }}$

Yang Prep dua apa?

'Yang ke dua apa?'

\section{'What is the second?}

This study found that there are many kinds and several forms of interference of Malay Manado Language toward Indonesian language, in phonological, morphological, and lexical which presents all the time on students' speech in class discussion performance. The data shows that, most of students in Indonesian Language Studies in Gorontalo State University made several kinds of interferences when they had class discussion performance. It seems that, they do not mastery Indonesian language well, especially in phonological and lexical. The researcher found the high interference on students speech between phonological, morphological and lexical interference was in lexical interference. When the researcher did research on students in Indonesian Language Studies, most of students have a capability to speak Indonesian well. But, when they had a class discussion especially in giving question and answer sesion they got interference from Malay Manado language without repairing the language. It happens regularly in each discussion and in every groups in class discussion performance. They had interference in phonological aspect that is assimilation, syncope, apocope, vowel modification, compression, and diftong. While in morphology aspect, they got interference in prefix addition, imperative form, reduplication, compounding form and negation form. Lastly, in lexical interference they had interference in verb, noun, adjective, adverb, personal pronoun, question form, language particle, possessive and preposition.

\section{Conclusions}

The conclusion from this study is most of students in Gorontalo State University in Indonesian Language Studies still make several kinds of interference on their speech in class discussion performance such as phonological interference, morphological inteference, and lexical interference. Where in phonological interference the students produced type of interference namely assimilation, merger coalescence or diphthong, syncope, apocope, compression, and lastly modification vowel. In morphological interference they produced prefix addition, imperative form, reduplication, compounding form and negation form. In 
Lexical interference, they created nine types of interference namely Verb, Noun, Adjective, Pronoun, Adverb, Question Form, Language Particle, Possessive, and the last is Preposition. Referring these conclusions, this study suggests that it is important for the students in Indonesian Language Studies to pay attention and make different between the use of Indonesian language and Malay Manado Language in formal and non formal situation especially in class discussion performance. The lecturer should give some comments or repairing students speech, when they produced interference from other language in a wrong way during in students' class discussion performance. 


\section{REFERENCES}

Chaer \& Agustina. (1995). Sosiolinguistik Suatu Pengantar. Jakarta: Rineka Cipta.

Furchan Ahmad. (2004). Pengantar Penelitian Dalam Pendidikan. Yogyakarta: Pustaka Belajar.

Mahsun. (2012). Metode Penelitian Bahasa, Tahapan Strategi,Metode dan Tekniknya. Jakarta: PT. Raja Grafindo Persada.

Nababan. (1991). Sosiolinguistik Suatu Pengantar. Jakarta: PT Gramedia Pustaka Utama

Pidu Sunarti. 2011. Language interference Malay Manado Dialect in Gorontalo Language in the South Dulomo, in family Domain (Tesis).

Poedjisoudarmo Soepomo. (1982). Interferensi dan Integrasi dalam situasi Keanekabahasaan. Pengajaran Bahasa dan Sastra Th.IV, No.2.

Suindratini. (2013). Interfeensi Bahasa Bali dan Bahasa Asing Dalam Cerita Lisan Bahasa Indonesia kelas VII Siswa SMP Negeri 10 Denpasar. E-Jurnal Program Pascasajana Universitas Pendidikan Ganesha, Volume 2. Denpasar: Universitas Pendidikan Ganesha.

Suwito. (1983). Pengantar Awal Sosiolinguistik Teori dan Praktik. Surakarta: Henary Offset.

Weda Sukardi. (1998). Interlanguage Phonology: Stress shifts of English utterances made by Indonesian Speakers of English (Tesis). Makassar: Universitas Hasanuddin. 